\title{
KAJIAN PEMANFAATAN ECENG GONDOK (Eichornia crassipes) SEBAGAI PAKAN TERNAK ITIK ALABIO (Anas platyrhynchos Borneo)
}

\author{
STUDY ON THE UTILIZATION OF WATER HYACINTH (EICHORNIA \\ CRASSIPES) $A S A N A L A B I O D U C K S$ (ANAS PLATYRHYNCHOS BorneO) \\ FEED
}

\section{Siska Fitriyanti}

Badan Penelitian dan Pengembangan Daerah Provinsi Kalimantan Selatan

Jalan Dharma Praja I Komplek Perkantoran Gubernur prov. Kalimantan Selatan, Banjarbaru, 70733

Pos el: siska.fitriyanti@kalselprov.go.id

\begin{tabular}{|c|c|}
\hline ARTICLE INFO & Abstract \\
\hline Article history & An efficient feeding strategy is utilizing abundant and nutritious local \\
\hline Received date & resources for livestock. Fermented hyacinths can be used as a substitute \\
\hline $2018-01-11$ & feed for ducks, which are widely available in natureand still not well \\
\hline Received in revised form date & $\begin{array}{l}\text { utullzed. On the other hand, water hyactnth also has a falrly good } \\
\text { nutritional content to serve as a ducks feed intake. The purpose of this }\end{array}$ \\
\hline 2019-07-14 & study is to determine the effect of feed consisting of water hyacinth \\
\hline Accepted date & $\begin{array}{l}\text { fermentation to the growth of Alabio ducks. The results obtained } \\
\text { were feed with } 75 \% \text { concentration of fermented hvacinths giving the }\end{array}$ \\
\hline 2019-07-15 & best result for Alabio duck growth when compared with duck given \\
\hline Available online date & commercial feed. \\
\hline
\end{tabular}

November 2019

Keywords: Water hyacinths, Eichornia crassipes, Alabio ducks, Fermented feed

Kata kunci:

Eceng gondok

Eichornia crassipes

Itik Alabio

Pakan fermentasi

\begin{abstract}
Abstrak
Strategi pemberian pakan yang efisien adalah memanfaatkan sumber daya lokal yang melimpah dan bernilai gizi bagi ternak. Salah satunya adalah melalui pemanfaatan eceng gondok dengan cara fermentasi. Eceng gondok sebagai bahan pakan alternatif sangat mudah untuk didapatkan karena bahan ini tersedia banyak di alam dan masih belum termanfaatkan dengan baik. Eceng gondok juga memiliki kandungan nutrisi yang cukup tinggi untuk dijadikan sebagai pakan ternak unggas. Penelitian ini bertujuan untuk mengetahui pengaruh pakan yang terdiri atas eceng gondok fermentasi terhadap pertumbuhan itik Alabio. Hasil yang diperoleh adalah pakan dengan kadar 75\% eceng gondok fermentasi memberikan hasil terbaik untuk pertumbuhan itik alabio jika dibandingkan dengan ternak itik yang diberikan pakan komersil.
\end{abstract}




\section{PENDAHULUAN}

Eceng gondok (Eichornia crassipes) adalah gulma dan dianggap sebagai tanaman penganggu. Eceng gondok dapat tumbuh dan berkembang biak dengan cepat sehingga diperlukan upaya untuk menanganinya agar tidak mengganggu dan merusak lingkungan. Pemanfaatan eceng gondok dalam skala besar dapat menjadi salah satu cara pengendalian pertumbuhan eceng gondok (Güereña et al. 2015).

Saat ini eceng gondok dimanfaatkan sebagai tanaman yang dapat mengurangi pencemaran perairan karena memiliki kemampuan untuk menyerap bahan-bahan pencemar perairan seperti logam berat dan senyawa sulfid. (Shahabaldin Rezania, Ponraj, et al. 2016) menyatakan bahwa eceng gondok mampu mengasimilasi polutan logam berat dalam jumlah besar. Tingkat penyerapan limbah oleh eceng gondok ini juga sangat tergantung dengan tingkat optimal pertumbuhannya (Shahabaldin Rezania, Taib, et al. 2016; S Rezania et al. 2017).

Tanaman eceng gondok umumnya tumbuh secara liar di semua perairan umum di Indonesia. Pertumbuhannnya sangat cepat terutama apabila kondisi lingkungannya sangat mendukung. Tanaman eceng gondok dapat berkembang pesat dalam kondisi air yang mengandung nutrien yang tinggi, terutama di daerah yang memiliki kadar nitrogen, potassium dan posphat. Lingkungan perairan dengan tingkat salinitas yang tinggi sebenarnya berpengaruh negatif pada pertumbuhan (Eisa et al. 2012) dan produktivitas eceng gondok. Walaupun demikian ada beberapa tumbuhan dalam jenis ini yang memiliki mekanisme fisiologis untuk dapat bertahan dalam lingkungan bersalinitas tinggi (Wang et al. 2015).
Hasil analisis kimia menyatakan bahwa eceng gondok mengandung bahan organik yang kaya akan vitamin, mineral, dan lemak yang cukup tinggi. Kandungan proteinnya cukup tinggi, yaitu antara $12-18 \%$ dan memiliki kandungan asam amino yang cukup lengkap (Muchtaromah, Susilowati, and Kusumastuti 2012).

Beberapa bangsa itik lokal di Indonesia yang terkenal antara lain itik tegal, bali, mojosari, itik magelang, dan itik alabio (Maulani, Sutopo, and Kurnianto 2016). Itik alabio (Anas platyrhynchos Borneo) merupakan salah satu sumber plasma nutfah unggas lokal di Kalimantan Selatan yang mempunyai keunggulan sebagai penghasil telur produktif (Suryana 2016). Kemampuan produksi telur itik sangat dipengaruhi oleh kondisi lingkungan dan kualitas ransum. Bahan pakan yang digunakan peternak untuk menyusun pakan itik Alabio di Kalimantan Selatan sebagian besar sama, tetapi ada beberapa peternak yang menggunakan bahan pakan berbeda, disesuaikan dengan ketersedian bahan pakan lokal di daerah setempat.

Susunan ransum dalam pakan unggas yang baik seharusnya terdiri atas zat-zat makanan yang mengandung karbohidrat, lemak, protein, vitamin, dan mineral. Selain itu perlu juga diperhatikan kandungan energinya mengingat tingkat energi ransum sangat menentukan banyaknya makanan yang dikonsumsi.

\section{METODE}

Penelitian dilakukan di Balai Pengkajian dan Pengembangan Pertanian Terpadu (BP3T) yang terletak di kecamatan Tambang Ulang. kabupaten Tanah Laut, provinsi Kalimantan Selatan.

Bahan-bahan yang digunakan dalam penelitian ini adalah itik Alabio (umur 21 hari saat awal perlakuan), eceng gondok, 
pakan komersial, EM4 (Effective Microorganisms 4, suatu produk komersial yang merupakan cairan mengandung mikroorganisme fermentasi, berfungsi untuk memfermentasi bahan organik), molase, gula jawa, dedak, tepung ikan, mineral mix, dan vitamin unggas.

Peralatan yang digunakan adalah kandang itik, mesin tepung pakan, kolam, tempat makan dan minum itik, timbangan, dan label nama.

\section{Persiapan Kandang}

Kandang pemeliharaan itik terbuat dari bahan paring yang dicuci terlebih dahulu, kemudian dibuat menjadi ruang berukuran 2 × 2 meter untuk setiap perlakuan.

\section{Pembuatan Pakan Itik}

Fermentasi eceng gondok mengadaptasi metode dari penelitian Fitrihidjajati et al. (2015) yang telah dimodifikasi. Eceng gondok diambil dari perairan setempat sebanyak yang diperlukan selama penelitian. Akar eceng gondok dibuang, kemudian eceng gondok di potong-potong kecil ukuran 2-3 cm. Eceng gondok dikeringkan dengan cara dijemur untuk kemudian dilakukan proses fermentasi dengan cara menambahkan probiotik EM4, cairan molase, dan air gula, Eceng gondok kemudian disimpan dalam plastik (kedap udara, kondisi anaerob) selama 21 hari. Selanjutnya eceng gondok yang telah selesai difermentasi di timbang sesuai perlakuan dan dotambahkan dengan bahan lain. Pakan konsentrat diberikan sebanyak $30 \%$ dari biomassa itik dengan frekuensi tiga kali sehari, yaitu pagi, siang, dan sore.

\section{Rancangan Percobaan}

Percobaan dilakukan dengan menggunakan Rancangan Acak Lengkap (RAL), terdiri atas empat perlakuan dan tiga ulangan, setiap perlakuan menggunakan lima ekor itik Alabio (tiga ulangan) seperti disajikan pada Tabel 1.

Tabel 1. Kelompok perlakuan

\begin{tabular}{cccc}
\hline Kode & $\begin{array}{c}\text { Eceng } \\
\text { Gondok }\end{array}$ & $\begin{array}{c}\text { Tepung } \\
\text { Ikan }\end{array}$ & Dedak \\
\hline A & $100 \%$ pakan & komersil & (kontrol) \\
B & $25 \%$ & $31 \%$ & $44 \%$ \\
C & $50 \%$ & $16 \%$ & $34 \%$ \\
D & $75 \%$ & $3 \%$ & $22 \%$ \\
\hline
\end{tabular}

Parameter yang dilihat dalam penelitian ini adalah perbandingan perkembanganbobotitikantar-kelompokperlakuan. Bobot itik ditimbang setiap dua minggu sekali sebanyak empat kali penimbangan (kurang lebih selama dua bulan). Selain itu juga diamati data sintasan (persentase jumlah itik yang hidup). Perbedaan antara perlakuan untuk setiap parameter uji dilihat melalui uji $\mathrm{F}$ (sidik ragam) pada tingkat kepercayaan 95\%. Uji lanjutan digunakan bila uji $\mathrm{F}$ memberikan hasil berbeda nyata (Gomez and Kwancai 1995).

\section{HASIL DAN PEMBAHASAN}

Hasil analisis laboratorium sesudah dan sebelum fermentasi disajikan pada Tabel 2. Data pada Tabel 2 menunjukkan bahwa kadar protein eceng gondok fermentasi lebih tinggi daripada eceng gondok non-fermentasi, sedangkan kadar air dan kadar serat kasar eceng gondok fermentasi lebih rendah daripada eceng gondok non-fermentasi. Hal ini mengindikasikan eceng gondok fermentasi memiliki kualitas zat yang lebih baik untuk diolah sebagai pakan ternak. 
Tabel 2. Hasil analisis uji laboratorium terhadap kandungan eceng gondok (\%)

\begin{tabular}{lcc}
\hline $\begin{array}{c}\text { Parameter } \\
\text { analisis }\end{array}$ & $\begin{array}{c}\text { Eceng } \\
\text { Gondok }\end{array}$ & $\begin{array}{c}\text { Eceng Gondok } \\
\text { Fermentasi }\end{array}$ \\
\hline Kadar air & 92,6 & 82,35 \\
Kadar abu & 9,5 & 7,42 \\
Kadar protein & 1,00 & 14,78 \\
Kadar lemak & 0,2 & 0,08 \\
Kadar serat & 20,12 & 16,49 \\
kasar & Sumber: Hasil Analisis Laboratorium Nutrisi dan \\
Makanan Ternak Fakultas Pertanian Universitas \\
Lambung Mangkurat (2017)
\end{tabular}

Itik yang telah dibagi menjadi empat kelompok perlakuan dengan kombinasi pakan yang berbeda ditimbang bobotnya setiap dua minggu sekali sebanyak empat kali. Data hasil penimbangan disajikan dalam bentuk tabel dan grafik sebagai berikut.

Tabel 3. Pertumbuhan Berat Mutlak Itik (Kg)

\begin{tabular}{cccccc}
\hline \multirow{5}{*}{ Prup } & $\mathbf{1}$ & $\mathbf{2}$ & $\mathbf{3}$ & $\mathbf{4}$ & \\
\hline A1 & 3,86 & 4,9 & 8,22 & 9,43 & 5,57 \\
A2 & 3,785 & 4,4 & 6,43 & 6,07 & 2,285 \\
A3 & 4,245 & 4,95 & 7,4 & 8,59 & 4,345 \\
B1 & 4,255 & 4,485 & 6,29 & 7,74 & 3,485 \\
B2 & 3,88 & 4,632 & 7,23 & 7,15 & 3,27 \\
B3 & 4,035 & 5,22 & 7,09 & 7,88 & 3,845 \\
C1 & 3,72 & 4,83 & 6,79 & 6,57 & 2,85 \\
C2 & 4,05 & 5,13 & 7,7 & 8,37 & 4,32 \\
C3 & 3,98 & 5,03 & 8,27 & 8,47 & 4,49 \\
D1 & 3,61 & 4,445 & 7,7 & 8,7 & 5,09 \\
D2 & 4,285 & 4,99 & 7,04 & 8,09 & 3,805 \\
D3 & 4,015 & 5,97 & 8,53 & 9,79 & 5,775 \\
\hline Sumber: Data primer yang & diolah $(2017)$ &
\end{tabular}

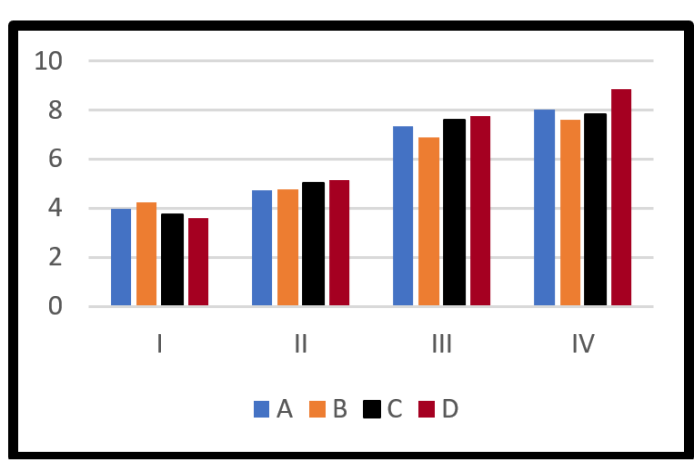

Gambar 1. Grafik pertumbuhan berat mutlak itik

Berdasarkan Tabel 3 dan Gambar 1, terlihat bahwa di akhir penimbangan, pertumbuhan yang paling tinggi terdapat pada kelompok perlakuan D, yaitu pakan dengan $75 \%$ eceng gondok fermentasi. Pertumbuhan kelompok D bahkan melebihi pertumbuhan kelompok A (kontrol). Hal ini sepertinya disebabkan pakan kelompok D lebih diminati ternak itik sehingga konsumsi pakan lebih optimal. Tingkat pertumbuhan terendah didapat dari kelompok B, dengan kandungan eceng gondok 25\%. Hal ini kemungkinan disebabkan tekstur pakan kurang disukai oleh ternak itik. Tekstur pakan B masih cukup kasar karena komposisi eceng gondok yang lebih sedikit daripada campuran dedak dan mineral campuran lainnya, sehingga kandungan air yang didapat dari eceng gondok lebih sedikit. Dengan demikian hal ini juga menjelaskan mengapa pakan D lebih disukai ternak itik. Komposisi eceng gondok yang lebih tinggi juga mengandung air yang lebih banyak, sehingga hasil akhir pakan campuran menjadi lebih lembut.

\section{Sintasan}

Sintasan adalah persentase dari semua jumlah itik yang hidup pada setiap perlakuan selama percobaan atau daya kelangsungan hidup. Hasil penelitian yang dilakukan selama 60 hari memperlihatkan bahwa nilai rerata sintasan cukup bervariasi berkisar 93,33-100\% dapat dilihat pada Tabel 4. 
Tabel 4. Persentase Sintasan (\%) itik Alabio

\begin{tabular}{ccccc}
\hline \multirow{2}{*}{ Ulangan } & \multicolumn{4}{c}{ Kelangsungan Hidup (\%) } \\
& A & B & C & D \\
\hline 1 & 80 & 80 & 100 & 100 \\
2 & 80 & 100 & 80 & 100 \\
3 & 60 & 100 & 100 & 80 \\
Jumlah & $\mathbf{2 2 0}$ & $\mathbf{2 8 0}$ & $\mathbf{2 8 0}$ & $\mathbf{2 8 0}$ \\
Rata-rata & $\mathbf{7 3 , 3}$ & $\mathbf{9 3 , 3}$ & $\mathbf{9 3 , 3}$ & $\mathbf{9 3 , 3}$ \\
\hline
\end{tabular}

Data yang disajikan pada Tabel 4 dan Gambar 1 memperlihatkan persentase daya kelangsungan hidup yang secara statistik tidak terdapat perbedaan yang nyata. Nilai terendah pada perlakuan A (73,3\%). Alasan persentase daya hidup kelompok A (pakan komersil) paling terendah diduga karena perebutan pakan yang terjadi di antara itik dalam kandang.

Perlakuan B, C, dan D mempunyai sintasan yang sama, yaitu $93,3 \%$, hal ini diduga karena pemberian pakan yang sudah diberikan sesuai rumus dan masa aklimatisasi pada pakan yang dibuat sehingga daya tarik dan respon itik pada pakan tersebut masih dalam tahap pembiasaan, sehingga tidak terjadi persaingan mendapatkan pakan seperti hanya pada kelompok A. Walaupun demikian seiring waktu pemeliharaan respon dan daya tarik itik terhadap pakan yang terbut dari eceng gondok fermentasi semakin lama maka akan semakin meningkat.

\section{Rasio Konversi Pakan (FCR)}

FCR merupakan gambaran tentang tingkat efisiensi pakan yang diberikan. Semakin kecil rasio konversi pakan, semakin efisien pakan yang diberikan dalam menunjang pertumbuhan itik. Hasil penelitian yang dilakukan selama 60 hari memperlihatkan bahwa nilai rerata FCR cukup bervariasi. Nilai rasio konversi pakan digunakan untuk mengetahui baik buruknya pakan yang diberikan untuk pertumbuhan itik Alabio. Data total pakan yang diberikan dan FCR itik Alabio selama penelitian dapat dilihat pada Tabel 5.

Tabel 5. Data Rerata rasio konversi pakan (FCR) selama penelitian

\begin{tabular}{cccccc}
\hline $\begin{array}{c}\text { Per- } \\
\text { lakuan }\end{array}$ & $\mathbf{1}$ & $\mathbf{2}$ & $\mathbf{3}$ & Jumlah & Rerata \\
\hline A & 0,42 & 0,69 & 0,46 & 1,57 & 0,785 \\
B & 0,57 & 0,78 & 0,61 & 1,96 & 0,98 \\
C & 0,78 & 0,5 & 0,58 & 1,86 & 0,93 \\
D & 0,46 & 0,41 & 0,48 & 1,35 & 0,675 \\
\hline Sumber: data primer yang telah diolah (2017)
\end{tabular}

Pada Tabel 5 memperlihatkan rerata FCR. Secara statistik tidak terdapat perbedaan yang nyata antar perlakuan. FCR terbaik terdapat pada perlakuan $\mathrm{D}(0,675)$, kemudian diikuti oleh perlakuan A $(0,78)$ dan $C(0,93)$ dan yang terakhir perlakuan $B$ $(0,98)$. Semakin tinggi nilai konversi pakan berarti semakin rendah daya guna pakan. Tingginya konversi pakan disebabkan oleh rendahnya daya cerna bahan pakan karena tingginya kandungan serat kasar dalam ransum yang menyebabkan daya cerna zat-zat makanan lainnya menurun. FCR perlakuan D lebih baik karna jumlah bahan eceng gondok fermentasi yang diberikan lebih banyak, yaitu 75\% sehingga kadar air dalam kandungan eceng gondok lebih besar sehingga tekstur dan aroma pakan lebih lembut dan menarik nafsu makan itik sedangkan perlakuan yang terbesar, yaitu pada perlakuan B karena perlakuan ini merupakan pemberian pakan dengan komposisi eceng gondok $25 \%$, tepung ikan $31 \%$ dan dedak $44 \%$, dengan demikian tekstur yang dihasilkan dari bahan eceng gondok 25\% ini teksturnya kasar dan aromanya menyengat karena kadar air pada perlakuan B sangat sedikit sehingga tekstur dan aroma pakan tidak disenangi dan daya tarik itik kurang pada pakan tersebut 
sehingga pakan yang diberikan sering tersisa banyak.

Penelitian yang dilakukan oleh Rompas et al. (2016) yang juga menggunakan eceng gondok fermentasi sebagai campuran ransum itik yang bertujuan untuk mengetahui pengaruh efek eceng gondok fermentasi dalam kecernaan bahan kering dan bahan organik. Penelitian mereka menyatakan bahwa eceng gondok dapat digunakan hingga 30\% dalam ransum pakan itik berdasarkan kemampuan cerna bahan kering dan organiknya. Penelitian ini sampai pada aplikasi pemberian pakan terhadap itik Alabio yang berumur di atas delapan minggu (Rompas et al. 2016). Dengan demikian terdapat perbedaan dengan hasil penelitian terdahulu, bahwa ternyata eceng gondok fermentasi dapat dimasukkan sebagai penyusun ransum hingga $75 \%$ dan menghasilkan nilai bobot tertinggi pada itik Alabio usia sebelas minggu.

\section{KESIMPULAN}

Eceng gondok yang difermentasi memiliki kandungan protein yang lebih tinggi. Oleh karena itu eceng gondok fermentasi berpotensi besar sebagai bahan baku pakan ternak. Kadar eceng gondok sebanyak 75\% dalam komposisi pakan terbukti lebih berpengaruh positif pada pertumbuhan ternak itik. Dengan demikian, penggunaan eceng gondok selain baik dari segi nutrisi, juga mampu mengurangi biaya pakan ternak.

\section{UCAPAN TERIMA KASIH}

Terima kasih penulis ucapkan untuk semua pihak yang terlibat dalam kegiatan penelitian ini, terutama bagi Balai Penelitian dan Pengembangan Terpadu (BP3T) prov. Kalimantan Selatan, yang sekarang sudah berganti nomenklatur menjadi Balai Pelatihan Pertanian Terpadu (BP2T) provinsi Kalimantan Selatan.

\section{DAFTAR ACUAN}

Bayyinatul, M, R Susilowati, and A Kusumastuti. 2012. "Pemanfaatan Tepung Hasil Fermentasi Eceng Gondok (Eichornia crassipes) sebagai Campuran Pakan Ikan untuk Meningkatan Berat Badan dan Daya Cerna Protein Ikan Nila Merah (Oreochromis sp)." Jurnal Universitas Negeri Malang.

Eisa, S, S Hussin, N Geissler, and H W Koyro. 2012. "Effect of NaCl Salinity on Water Relations, Photosynthesis and Chemical Composition of Quinoa(Chenopodium quinoa Wild) As A Potential Cash Crop Halophyte." Aust. J. Crop. Sci 357 - 368.

Gomez K. A dan Gomez A. A. 1995. Prosedur Statistik Untuk Penelitian Pertanian. Edisi Kedua. Jakarta: UIPress.

Guerena, D, H Neufeldt, J Berazneva, and S Duby . 2015. "Water hyacinth control in Lake Victoria: Transforming An Ecological Catastrophe Into Economic, Social, and Environmental Benefits." Suistainable Production and Consumption (3) 59 - 69.

Maulani, N L, Sutopo, and E Kurnianto. 2016. "Keragaman Genetik Itik Magelang Berdasarkan Lebar Kalung Leher Melalui Analisis Protein Plasma Darah di Satuan Kerja Itik Banyubiru Ambarawa." Jurnal Sain Peternakan Indonesia 11 (1) 23 - 30.

Rezania, S, M FM Din, S M Taib, F A Dahalan, and A R Songip. 2016a . "The Efficient Role of Aquatic Plant (Water Hyacinth) In Treating Domestic Wastewater In Continuous System." Int $J$ Phyto Remediation 18(7) 679 - 685.

Rezania, S, M Ponraj, A Talaiekhozani, S E Mohamad, and M FM Din. 2015. "Perspectives of Phyto Remediation Using Water Hyacinth For Removal of Heavy Metals, Organic And In- 
organic Pollutants in Wastewater." Journal of Environmental Management (163) 125 - 133.

Rezania, S, M Ponraj, Md Din M Fadhil, S Chelliapan, and F MdSairan. 2016b. "Effectiveness of Eichhornia crassipes In Nutrient Removal From Domestic Wastewater Based On Its Optimal Growth Rate. Desalination and Water Treatment 57(1) 360 - 365.

Rompas, R, B Tulung, J S Mandey, and M Regar. 2016. "Penggunaan Eceng Gondok Terfermentasi (Eichhornia crassipes) Terfermentasi dalam Ransum Itik Terhadap Kecernaan Bahan Kering dan Bahan Organik." Jurnal Zootek 36(2). 372 - 378.

Suryana. 2013. "Pemanfaatan Keragaman Genetik Untuk Meningkatkan Produktivitas Itik Alabio (Anas platyrhynchos Borneo)." Jurnal Penelitian dan Pengembangan Pertanian 32 (3) $100-111$.

Wang, J. 2015. "Physiological And Proteomic Analyses of Salt Stress Response In The Halophyte Halogeton glomeratus." Plant Cell Environ 655 $-669$. 